cysts as to be unrecognisable." There were no growths on the parietal pleura on either side of the carcase.

In view of the presence of ciliated epithelium it is unfortunate that the uterus and its appendages had been destroyed, as an examination of these might have shed some light on the question as to what was the starting point of the growths.

\title{
POISONING OF POULTRY BY COMMON SALT*
}

By EDWARD R. EIWARDs, F.R.C.V.S., Board of Agriculture and Fisheries.

IN the issue of this Journal for March I9Io there is an abstract of an article in the Rev. Gín. de Méd. Vét. on the poisonous effect of common salt on poultry, and a case has recently come to my knowledge resembling the previously recorded one, as the following note will show.

Briefly, the facts are these: A railway station master had thirtyfour fowls, and they had always been in good health; on going to the fowl-house one morning he found twenty-one of them dead, although they had been a.pparently quite well the night before, and he could not imagine the cause. Enquiry elicited the information that the man's wife had been doing some house-cleaning and had turned out, into a bucket, the contents of the box in which the domestic stock of salt was kept. The man then put some boiled potatoes into the bucket, and mashed them up with the salt, and fed the fowls with the mixture, with the result that twenty-one birds out of thirty-four died within a few hours. Some of those left alive refused food and were very weak for a few days, but their appetite and strength gradually returned.

The carcases of the dead birds had been buried some little time before the veterinary surgeon appeared on the scene; two of them were exhumed and a quantity of potato was found in the crops, but detailed post-mortem examinations were not practicable. There was no history of any circumstance pointing to any other poison, and the deaths were attributed to the ingestion of salt.

\section{ACID-FAST BACILLI IN CAMEL'S LUNG WITH LES- IONS RESEMBLING THOSE OF TUBERCULOSIS.}

By A. S. LeEsE, M.R.C.V.S., Civil Veterinary Department, India, Investigating Camel Diseases.

IN the March number of the Joumal (Vol. XXIII., p. 56) Captain R. G. Archibald, R.A.M.C., reports a case under a heading similar to the above, and says: "In the literature at my disposal I cannot find any previous reference to such a condition existing in camels."

Apart from cases in zoological gardens, in which camels lead a confined and unnatural existence, the following are records of two similar cases in India :-

Lingard (Annual Report of Imperial Bacteriolorist India Tone-nh) 